\title{
Water quality affects the structure of copepod assemblages along the Sfax southern coast (Tunisia, southern Mediterranean Sea)
}

\author{
Zaher Drira ${ }^{\mathrm{A}, \mathrm{D}}$, Salma Kmiha-Megdiche ${ }^{\mathrm{A}}$, Houda Sahnoun ${ }^{\mathrm{B}}$, Marc Pagano $^{\mathrm{C}}$, \\ Marc Tedetti ${ }^{\mathrm{C}}$ and Habib Ayadi ${ }^{\mathrm{A}}$ \\ A Biodiversity and Aquatic Ecosystems UR/11ES72 Research Unit, Department of Life Sciences, \\ Sfax Faculty of Sciences, University of Sfax, Soukra Road kilometre 3.5, BP 1171, 3000 Sfax, \\ Tunisia. \\ ${ }^{B}$ Coastal and Urban Environment Research Unit, Sfax Preparatory Engineering Institute (IPEIS), \\ BP 901, 13288 Sfax, Tunisia. \\ ${ }^{\mathrm{C}}$ Aix-Marseille University, Centre Nationnal de la Recherche Scientifique, University of Toulon, \\ Research Institute for Development (IRD), Mediterranean Institute of Oceanography, UM 110, \\ 13288 Marseille, France. \\ ${ }^{D}$ Corresponding author. Email: zaherdrira@yahoo.fr
}

\begin{abstract}
The Sfax southern coast (Gulf of Gabes, Mediterranean Sea) has been under increased anthropogenic pressure for many years. In the present study we investigated the effects of this anthropisation on the spatial distribution of copepod assemblages in relation to the physicochemical features of seawater at 20 stations sampled on 19 March 2013. Copepods represented $73 \%$ of total zooplankton abundance. Small planktonic copepods $(<1.45 \mathrm{~mm})$, including pollution-tolerant species (e.g. Oithona nana, Paracalanus parvus, Harpacticus littoralis and Tisbe battagliai), proliferated exclusively in stations of $\sim 0.5$-m depth characterised by high coastal anthropogenic inputs. The largest copepod species were dominated by Calanus helgolandicus $(1.45-2.5 \mathrm{~mm})$ in the offshore zone in depths of $\sim 3 \mathrm{~m}$. Substantial numbers of Oithona plumifera $(7.5 \%)$ were found at depths between 0.5 and $3 \mathrm{~m}$. Copepod diversity was significantly higher in the southern zone, which is less affected by sewage, than in the northern zone, which was subjected to higher pressure (ShannonWiener index $H^{\prime}=1.5-2.5$ and $\leq 1.5$ bits individual ${ }^{-1}$ ). A shift in the planktonic copepod community between the two zones was linked to deterioration of water quality, with higher phosphorus levels, turbidity and chemical oxygen demand (COD) in the northern zone.
\end{abstract}

Additional keywords: anthropogenic inputs, chemical oxygen demand-5-day biochemical oxygen demand, COD$\mathrm{BOD}_{5}$, diversity, zooplankton.

\section{Introduction}

Plankton represents the base of the marine food web and thus plays a pivotal role in fisheries. Primary productivity and plankton growth are closely related to the physicochemical parameters of seawater (i.e. light, nutrients and oxygen; Shastri 2000; Gang et al. 2006; Khwaja et al. 2014). Zooplankton is an essential component of the aquatic ecosystem. It is the faunal component that occupies the primary consumer level and forms a link between microscopic photosynthetic algae and fish (Madin et al. 2001; Sundaresan and Kumar 2013). Zooplankton feed on phytoplankton and are, in turn, consumed by fish and macroinvertebrates (Sharma 1998; Biswas 2015). Zooplankton communities depend on the nutrient content of an ecosystem and rapidly respond to changes in nutrient content (Dodson 1992). Their diversity and abundance are very sensitive to any changes in physicochemical conditions, thus providing information about the health of an aquatic system and of any damage and threat to the ecosystem (Rosenberg and Resh 1993; Biswas 2015; Sanyal et al. 2015). Zooplankton is not only a pertinent bioindicator of pollution load, but can also be used to assess the changing trophic status of an aquatic system (Mukhopadhyay et al. 2007; Kushwaha and Agrahari 2014; Sanyal et al. 2015).

The Sfax southern coast (southern Mediterranean Sea, Tunisia) has been under increased anthropogenic pressure for many years due to industrial activities, including phosphate treatment, ship activity in commercial and fishing harbors, agricultural activity, including salt marshes and the storage of olive oil waste (margins), and the dumping of considerable volumes of urban waste in the Thyna landfill and municipal wastewater treatment plants (Zaghden et al. 2005; Gargouri 2006; Choura et al. 2015). Hence, in the southern part of Sfax, many different sources release diverse compounds into marine waters, including 


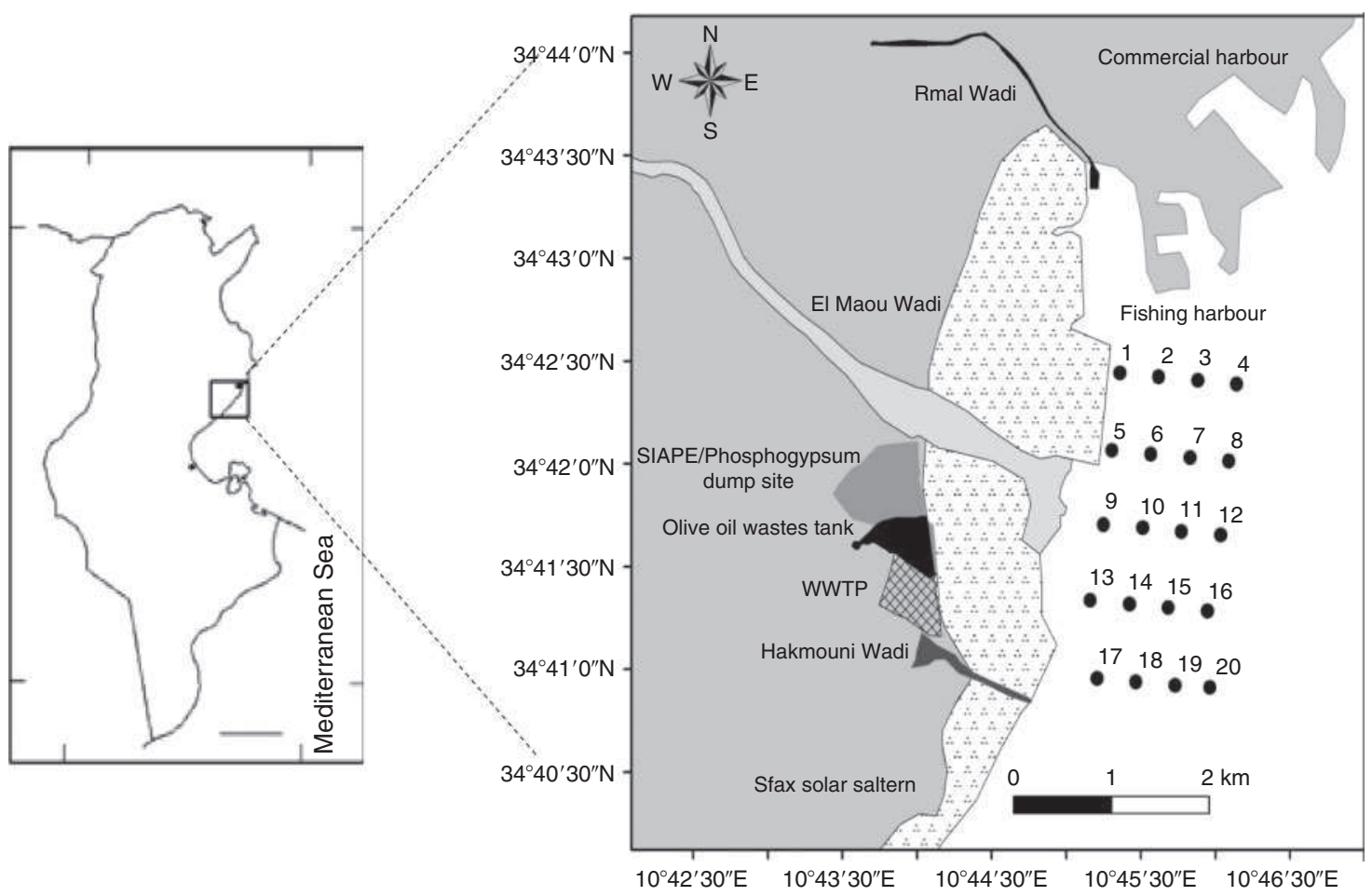

Fig. 1. Location of the study stations along the southern coast of Sfax (Tunisia) in the southern Mediterranean Sea, sampled in spring (March 2013).Stations 1-10, northern stations; Stations 11-20, southern stations. SIAPE, phosphoric acid and fertiliser plant; WWTP, wastewater treatment plant (located in front of Station 9). The fishing harbour is located close to Stations 1 and 2.

phosphates, fluorides, sulfates, naturally occurring radionuclides, trace metals and other trace elements, hydrocarbons and polyphenolic and flavonoid compounds (Zaghden et al. 2005; Tayibi et al. 2009; Mezghani-Chaari et al. 2011). These discharges have led to increases in biological oxygen demand (BOD), dissolved oxygen (DO) and suspended particulate matter (SPM), in addition to changes in $\mathrm{pH}$, in the receiving water (Davis and Marshall 1998; Negi and Rajput 2013).

A recent study evaluated the water quality along the Sfax southern coast by analysing physicochemical parameters (temperature, salinity, $\mathrm{pH})$, major anions $\left(\mathrm{Cl}^{-}, \mathrm{HCO}_{3}^{-}, \mathrm{SO}_{4}{ }^{2-}, \mathrm{F}^{-}\right)$, major cations $\left(\mathrm{Ca}^{2+}, \mathrm{K}^{+}, \mathrm{Mg}^{2+}, \mathrm{Mn}^{2+}, \mathrm{Fe}^{2+}\right.$ and $\left.\mathrm{Fe}^{3+}\right)$ and biogeochemical parameters (nutrients, turbidity, SPM, total polyphenolic and flavonoid compounds, chemical oxygen demand (COD), 5-day BOD $\left(\mathrm{BOD}_{5}\right)$; Drira et al. 2016). The Sfax northern coast has been partly restored as part of the Taparura Project, including rehabilitation of the site of a former industrial complex, cleaning up of beaches and restoration of the area (Callaert et al. 2009). This project led to significant improvements in plankton communities and water quality (Rekik et al. 2013a). For this reason, a future project restoring the southern area is deemed necessary to ameliorate the biological quality of the seawater (primarily planktonic aspects).

The aims of the present study were to: (1) investigate the spatial distribution of zooplankton (copepod) assemblages along the Sfax southern coast; and (2) assess relationships between zooplankton composition and the physicochemical parameters of seawater, which were determined in the same samples and published previously (Drira et al. 2016), using multivariate analysis. To the best of our knowledge, the present study is the first to evaluate the effects of anthropogenic inputs on the structure and spatial distribution of copepod assemblages in along the southern Sfax coast.

\section{Materials and methods}

\section{Study area and sampling}

The study area was along the coastline of Sfax city $\left(34^{\circ} 44^{\prime} \mathrm{N}\right.$, $10^{\circ} 46^{\prime} \mathrm{E}$ ), located in the south-east of Tunisia in the northern part of the Gulf of Gabes (southern Mediterranean Sea; Fig. 1). The area is characterised by shallow waters and an important biodiversity with endemic Posidonia oceanica seagrass beds, which were replaced by green tides caused by coastal Ulva rigida (Ben Brahim et al. 2010). Despite its ecological significance, the southern Sfax coast has been user serious threat for many decades from maritime, urban and industrial activities. The major sources of pollution include urban and industrial wastewaters, the fishing harbour and phosphate-processing coproducts (Aloulou et al. 2012). The main industries in Sfax are phosphates, chemical products, textiles, olive oil, food, soap and paint (Barhoumi et al. 2009).

In the present study, 20 stations were sampled at high tide during a spring cruise conducted on 19 March 2013 along the Sfax southern coast on the vessel Taparura. Station depths ranged from 0.3 to $3.5 \mathrm{~m}$ (Figs $1,2 a$ ). Stations located in the northern part of this area (S1-10) were the most affected by sewage from the El Maou wadi, the phosphate industry and the waste water treatment plant (WWTP), whereas stations located in the southern part of this area (S11-20), bordering the solar 

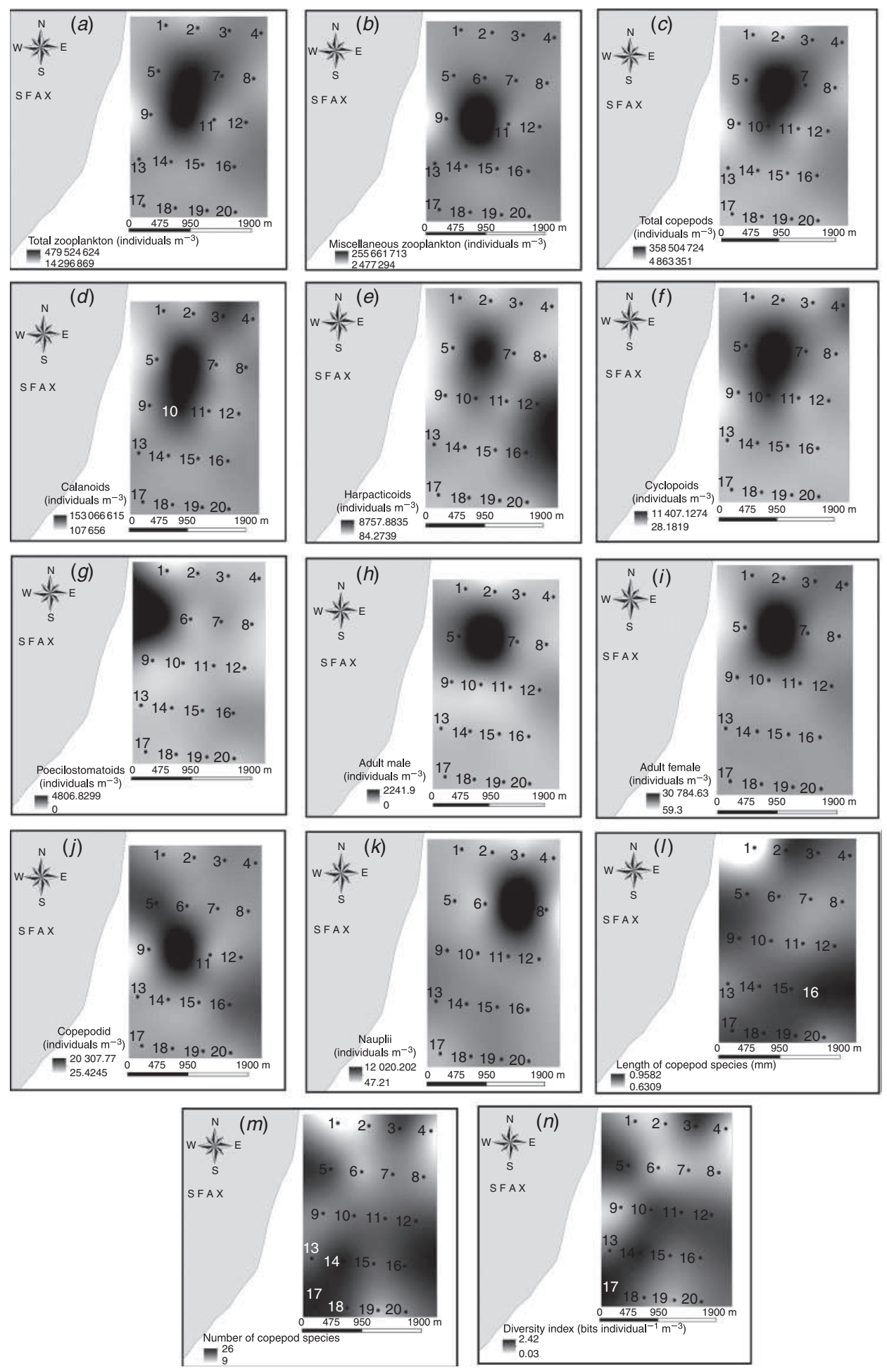

Fig. 2. Spatial variation of zooplankton parameters at Stations 1-20 sampled off the southern coast of Sfax in spring (March 2013): abundance of $(a)$ total zooplankton, $(b)$ miscellaneous zooplankton, $(c)$ total copepods, $(d)$ calanoids, $(e)$ harpacticoids, $(f)$ cyclopoids, $(g)$ poecilostomatoids, $(h)$ adult males, $(i)$ adult females, $(j)$ copepodids and $(k)$ nauplii; $(l)$ size of copepod species; $(m)$ number of copepod taxa; and $(n)$ diversity index. 
saltern marsh, were less affected although they did receive inputs from the Hakmouni wadi (Fig. 1).

Zooplankton was collected using a cylindroconical net (aperture $30 \mathrm{~cm}$, height $100 \mathrm{~cm}$, mesh size $100 \mu \mathrm{m}$ ) equipped with a Hydro-Bios flowmeter (mechanical flow meter HB 438 111, Muchtar Tabrani, Bekasi, Indonesia, see https://www. jualo.com/elektronik/iklan-hydro-bios-flow-meter_2, accessed 14 September 2017). The net was towed obliquely from near bottom to the surface at each station at a mean speed of $1 \mathrm{~m} \mathrm{~s}^{-1}$ over a period of $4 \mathrm{~min}$. After collection, zooplankton samples $(200 \mathrm{~mL})$ were rapidly preserved in a buffered formaldehyde solution (2\%). Samples were subsequently stained with Rose Bengal to identify the internal tissues of the different zooplankton species and to facilitate copepod dissection.

\section{Zooplankton analysis}

Zooplankton samples were identified according to Rose (1933), Bradford-Grieve (1999) and Costanzo et al. (2000). The different copepod species were sorted into four demographic classes (nauplii, copepodids, adult males and adult females). Miscellaneous zooplankter were also counted according to Tregouboff and Rose $(1978 a, 1978 b)$. Enumeration of the entire zooplankton sample was performed under a vertically mounted deep-focus dissecting microscope (TL 2; Olympus Australia Pty Ltd, Melbourne, Vic., Australia) and numerical density was expressed as the number of individuals per cubic metre. The total length of the body of adult copepods was measured for each species in each station sampled (10 individuals for each species in each sample). The body lengths of the different copepod species were measured using an eyepiece micrometer and taking into consideration the several body parts that make up the whole body. The sex ratio (expressed as a percentage) was estimated for each copepod species according to Wiwatanaratanabutr and Grandjean (2016) as follows:

number of males $\div$ (number of males + number of females $) \times 100$

\section{Data processing and statistical analysis}

Geographic information systems (GIS) tools through ArcGIS, ver. 10.2 (Esri, Redlands, CA, USA), were used to create contour plots. Kriging was the method used to build maps relative to spatial distribution for all dataset parameters. Mesozooplankton diversity was measured using a range of univariate and multivariate diversity measurements. Species were assessed using the Shannon-Wiener index, $H^{\prime}$ (Shannon and Weaver 1949):

$$
H^{\prime}=-\sum_{n i}^{i=1} \frac{n i}{N} \log _{2} \frac{n i}{N}
$$

where $n_{i}$ is the number of individuals of taxon $i$ in the sample and $N$ is the total number of organisms of all species. The dominance index, $\delta$, for copepod species was calculated using to the following formula:

$$
\delta=\left(n_{1}+n_{2}\right) \div N
$$

where $\delta$ is the dominance index equal to the percentage contribution of the two most important species $\left(n_{1}+n_{2}\right)$ of the total standing stock and $N$ is total individual abundance. Unpaired Student's $t$-tests were used to evaluate differences between the northern (S1-10) and southern (S11-20) stations in terms of physical, physicochemical and biogeochemical parameters with a confidence level of 95\%. Differences were considered significant at $P<0.05$.

The spatial variability of copepod communities in relation to environmental variables was assessed using multivariate analysis after $\log _{10}(x+1)$ data transformation (Sokal and Rohlf 1981). Analyses were conducted using two datasets, the first containing the frequencies of copepod taxa and the second containing the environmental and trophic variables, with the diversity index $\left(H^{\prime}\right)$ considered as an independent variable. Factorial correspondence analysis (FCA) and principal component analysis (PCA) were performed on these two datasets respectively. The results of the two analyses were associated through a co-inertia analysis (Dolédec and Chessel 1994). Analyses were performed using Ade-4 software (Laboratory of Biometry, Genetics and Population Biology, University of Lyon 1, Lyon, France) (Thioulouse et al. 1997). Pearson's rank correlations were conducted using XLStat 2014 (Thierry Fahmy, University of California-Berkeley, Berkeley, CA, USA) to determine potential correlations between the copepod community and the physicochemical variables.

Data are given as the mean \pm s.d.

\section{Results}

\section{Spatial distribution of zooplankton according to environmental conditions}

Table 1 summarises the mean values of zooplankton parameters and selected environmental parameters using data from Drira et al. (2016) in the northern (S1-10) and southern (S11-20) stations.

Total zooplankton abundance varied from $1.43 \times 10^{3}$ individuals $\mathrm{m}^{-3}$ at S20 to $47.95 \times 10^{3}$ individuals $\mathrm{m}^{-3}$ at S10, with a mean of $10.25 \pm 12.55 \times 10^{3}$ individuals $\mathrm{m}^{-3}$ (Fig. $2 a$; Table 1). Zooplankton assemblages were dominated by copepods, which represented $73 \%$ of total zooplankton abundance, whereas the abundance of miscellaneous zooplankton did not exceed $27 \%$ (Table 2). The density of non-copepod zooplankton varied from $0.25 \times 10^{3}$ individuals $\mathrm{m}^{-3}$ at $\mathrm{S} 20$ to $25.57 \times 10^{3}$ individuals $\mathrm{m}^{-3}$ at $\mathrm{S} 10$, with a mean of $3.07 \pm 5.40 \times 10^{3}$ individuals $\mathrm{m}^{-3}$ (Fig. $2 b$; Table 1). Polychaete larvae, cirriped larvae, ostracods, jellyfish, zoea and fish eggs were also permanent components of meroplankton contributing to $81 \%$ of the non-copepod abundance. Conversely, appendicularians, cladocerans and foraminifera were permanent components of the holoplankton, but did not exceed $19 \%$ of miscellaneous zooplankton abundance (Table 2). Total copepod abundance varied from $0.49 \times 10^{3}$ individuals $\mathrm{m}^{-3}$ at S17 to $35.85 \times 10^{3}$ individuals $\mathrm{m}^{-3}$ at $\mathrm{S} 6$, with a mean of $7.18 \pm 8.89 \times 10^{3}$ individuals $\mathrm{m}^{-3}$ (Fig. $2 c$; Table 1).

In all, 27 different copepod species were identified during a single cruise in March 2013 belonging to four different orders: Calanoida, Cyclopoida, Harpacticoida and Poecilostomatoida (Table 2). Calanoida was the most diverse order (12 species), followed by Poecilostomatoida ( 6 species), Cyclopoida ( 5 species) and Harpacticoida (4 species), contributing to 39, 10, 29 and 22\% 
Table 1. Summary of zooplankton parameters (present study) and environmental variables (from Drira et al. 2016) along the Sfax southern coast in spring (March 2013) at the northern and southern stations

Data are the mean \pm s.d. The last column shows results of Student's $t$-tests for comparisons between northern (Stations 1-10) and southern (Stations 11-20) stations. Asterisks denote significant differences between Northern and Southern stations: *, $P<0.05$; **, $P<0.001$; ***, $P<0.0001$. NTU, nephelometric turbidity units; SPM, suspended particulate matter; $\mathrm{COD}$, chemical oxygen demand; $\mathrm{BOD}_{5}, 5$-day biochemical oxygen demand; Chl- $a$, chlorophyll- $a$

\begin{tabular}{|c|c|c|c|}
\hline & Northern stations & Southern stations & $|t|($ d.f) \\
\hline \multicolumn{4}{|l|}{ Physical and chemical parameters } \\
\hline Depth (m) & $1.59 \pm 1.06$ & $0.97 \pm 0.44$ & $1.95(18)$ \\
\hline Temperature $\left({ }^{\circ} \mathrm{C}\right)$ & $17.9 \pm 2.20$ & $15.20 \pm 0.80$ & $4.75(18)^{* * *}$ \\
\hline Salinity & $37.4 \pm 1.00$ & 40 & $4.20(18)^{* * *}$ \\
\hline $\mathrm{pH}$ & $7.86 \pm 0.14$ & $8.39 \pm 0.07$ & $9.00(18)^{* * *}$ \\
\hline \multicolumn{4}{|l|}{ Biogeochemical parameters } \\
\hline $\mathrm{NO}_{3}{ }^{-}(\mu \mathrm{M})$ & $6.44 \pm 2.70$ & $6.56 \pm 1.74$ & $0.26(18)$ \\
\hline $\mathrm{NO}_{2}{ }^{-}(\mu \mathrm{M})$ & $0.31 \pm 0.11$ & $0.32 \pm 0.14$ & $0.16(18)$ \\
\hline $\mathrm{NH}_{4}^{+}(\mu \mathrm{M})$ & $3.59 \pm 1.71$ & $4.25 \pm 1.36$ & $1.05(18)$ \\
\hline Total N $(\mu \mathrm{M})$ & $21.04 \pm 3.57$ & $21.22 \pm 2.82$ & $0.43(18)$ \\
\hline $\mathrm{PO}_{4}{ }^{3-}(\mu \mathrm{M})$ & $12.72 \pm 5.19$ & $9.65 \pm 2.72$ & $0.74(18)$ \\
\hline Total $\mathrm{P}(\mu \mathrm{M})$ & $32.78 \pm 12.86$ & $27.73 \pm 11.99$ & $0.47(18)$ \\
\hline $\mathrm{Si}(\mathrm{OH})_{4}(\mu \mathrm{M})$ & $33.15 \pm 16.64$ & $28.66 \pm 13.90$ & $0.04(18)$ \\
\hline $\mathrm{N} / \mathrm{P}$ ratio & $0.99 \pm 0.53$ & $1.26 \pm 0.51$ & $0.66(18)$ \\
\hline Turbidity (NTU) & $5.47 \pm 1.65$ & $0.58 \pm 0.24$ & $9.64(18)^{* * *}$ \\
\hline $\operatorname{SPM}\left(\mathrm{mg} \mathrm{L}^{-1}\right)$ & $29.45 \pm 6.95$ & $29.17 \pm 2.57$ & $1.04(18)$ \\
\hline $\mathrm{COD}\left(\times 10^{3} \mathrm{mg} \mathrm{L}^{-1}\right)$ & $2.13 \pm 0.58$ & $1.66 \pm 0.16$ & $1.71(18)^{*}$ \\
\hline $\mathrm{BOD}_{5}\left(\mathrm{mg} \mathrm{L}^{-1}\right)$ & $65.30 \pm 31.90$ & $55.30 \pm 26.50$ & $0.07(18)$ \\
\hline $\mathrm{BOD}_{5} / \mathrm{COD}$ & $0.03 \pm 0.01$ & $0.03 \pm 0.01$ & $0.77(18)$ \\
\hline $\mathrm{COD} / \mathrm{BOD}_{5}$ & $42.26 \pm 27.11$ & $37.94 \pm 19.07$ & $0.73(18)$ \\
\hline $\mathrm{SPM} / \mathrm{BOD}_{5}$ & $0.63 \pm 0.47$ & $0.67 \pm 0.35$ & $0.30(18)$ \\
\hline Chl- $a\left(\times 10^{-2} \mu \mathrm{g} \mathrm{L}^{-1}\right)$ & $0.64 \pm 0.56$ & $0.33 \pm 0.25$ & $1.60(18)$ \\
\hline \multicolumn{4}{|l|}{ Zooplankton } \\
\hline \multicolumn{4}{|l|}{ Abundance $\left(\times 10^{3}\right.$ individuals $\left.\mathrm{m}^{-3}\right)$} \\
\hline Total zooplankton & $15.40 \pm 16.28$ & $5.10 \pm 2.92$ & $1.69(18)$ \\
\hline Non-copepod zooplankton & $4.26 \pm 7.57$ & $1.88 \pm 0.97$ & $0.60(18)$ \\
\hline Total copepods & $11.14 \pm 11.23$ & $3.21 \pm 2.35$ & $2.10(18)^{*}$ \\
\hline Calanoids & $3.96 \pm 5.40$ & $0.30 \pm 0.36$ & $2.00(18)$ \\
\hline Harpacticoids & $1.76 \pm 2.69$ & $1.68 \pm 2.01$ & $0.62(18)$ \\
\hline Cyclopoids & $3.60 \pm 3.75$ & $0.61 \pm 0.64$ & $2.49(18)^{*}$ \\
\hline Poecilostomatoids & $0.68 \pm 1.47$ & $0.28 \pm 0.32$ & $0.21(18)$ \\
\hline Adult males & $0.38 \pm 0.72$ & $0.05 \pm 0.09$ & $0.65(18)$ \\
\hline Adult females & $5.09 \pm 9.25$ & $0.68 \pm 1.08$ & $3.11(18)^{* *}$ \\
\hline Copepodids & $3.95 \pm 6.37$ & $1.02 \pm 1.92$ & $1.84(18)$ \\
\hline Nauplii & $1.70 \pm 3.68$ & $1.44 \pm 0.61$ & $1.84(18)$ \\
\hline Length of copepod species (mm) & $0.84 \pm 0.08$ & $0.88 \pm 0.04$ & $1.34(18)$ \\
\hline Ratio males/adults (\%) & $13 \pm 30$ & $20 \pm 36$ & $0.46(18)$ \\
\hline Shannon index (bits individual ${ }^{-1}$ ) & $0.75 \pm 0.89$ & $1.54 \pm 0.63$ & $1.70(18)^{*}$ \\
\hline Number of copepod species & $16.70 \pm 4.59$ & $21.70 \pm 3.70$ & $2.59(18)^{*}$ \\
\hline Dominance index $(\%)$ & $53.54 \pm 18.08$ & $65.96 \pm 14.16$ & $2.61(18)^{* *}$ \\
\hline
\end{tabular}

of the total abundance respectively (Table 2). Among the calanoid copepods, Paracalanus parvus, Calanus helgolandicus and Paracartia latisetosa were the most abundant species, accounting for $14,7.5$ and $6.5 \%$ of total copepod abundance respectively. Among the cyclopoid copepods,Oithona nana and Oithona plumifera were the most abundant species, accounting for 14 and $7.5 \%$ of total copepod abundance respectively. Tisbe battagliai, Euterpina acutifrons and Harpacticus littoralis were the dominant harpacticoid species and accounted for 13,9 and $3.5 \%$ of total copepod abundance respectively. Among the poecilostomatoid copepods, Corycaeus clausi was dominant, accounting for $1.5 \%$ of total copepod abundance.
The peak abundance of copepod community recorded at S6 was associated with a high density of calanoids, harpacticoids, cyclopoids, adult males and adult females (Fig. $2 d-f, h, i, k$; Tables 1, 2). However, poecilostomatoid density and the percentage of males reached maximum values at S5 (Fig. 2g; Table 1). In all sampled stations, a low percentage of larvalstage (copepodids $35 \%$, nauplii $22 \%$ ) individuals (Table 2) and a high percentage of adults ( $43 \%$ of total copepod abundance) were recorded. There was a greater number of adult females than males (Table 2$)$, which affected the sex ratio ( $\%$ males). In fact, the sex ratio did not exceed $20 \%$ (Table 1). The ShannonWiener index $\left(H^{\prime}\right)$ for copepods was low, with values ranging 
Table 2. Taxonomic composition and quantitative aspects of the zooplankton community along the Sfax southern coast in spring (March 2013) Data are the mean \pm s.d. Stations with maximum abundance are listed for each taxon. RA, relative abundance; TL, total length; FO, frequency of occurrence; SWMSA, station with maximum species abundance

\begin{tabular}{|c|c|c|c|c|c|c|}
\hline Zooplankton & Abbreviation & RA (\%) & $\mathrm{TL}(\mathrm{mm})$ & FO $(\%)$ & Density (individuals $\mathrm{m}^{-3}$ ) & SWMSA \\
\hline \multicolumn{7}{|l|}{ Copepods $(73 \%)$} \\
\hline Small copepods $(\leq 1.45 \mathrm{~mm})$ & & 92.74 & & & & \\
\hline \multicolumn{7}{|l|}{ Calanoids } \\
\hline Acartia clausi (Giesbrecht, 1889) & $A c l$ & 0.49 & $1.010 \pm 0.001$ & 55 & 31.83 & 5 \\
\hline Acartia longiremis (Lilljeborg, 1853) & A lo & 0.06 & $1.220 \pm 0.004$ & 35 & 3.99 & 3 \\
\hline Acartia danae (Giesbrecht, 1889) & $A d a$ & 0.05 & $1.120 \pm 0.008$ & 45 & 3.42 & 3 \\
\hline Acartia sp. (Dana, 1846) & $A s p$ & 0.15 & $1.060 \pm 0.006$ & 50 & 9.45 & 14 \\
\hline Paracalanus parvus (Claus, 1863) & Parp & 14.01 & $1.010 \pm 0.005$ & 100 & 905.80 & 10 \\
\hline Paracartia grani (Sars, 1904) & Parg & 0.14 & $1.150 \pm 0.007$ & 40 & 8.99 & 3 \\
\hline Paracartia latisetosa (Kritchagin, 1873) & Parl & 6.32 & $1.200 \pm 0.007$ & 75 & 408.90 & 6 \\
\hline Temora longicornis (Müller, 1792) & Tem $l$ & 1.20 & $1.020 \pm 0.011$ & 75 & 77.34 & 3 \\
\hline Centropages typicus (Kroyer, 1849) & Cent & 3.09 & $1.400 \pm 0.010$ & 25 & 200.10 & 6 \\
\hline Isias clavipes (Boeck, 1865) & Isi & 0.10 & $1.240 \pm 0.015$ & 50 & 6.22 & 17 \\
\hline \multicolumn{7}{|l|}{ Harpacticoids } \\
\hline Clytemnestra scutellata (Dana, 1847) & Cly & 1.34 & $0.600 \pm 0.010$ & 25 & 86.84 & 10 \\
\hline Euterpina acutifrons (Dana, 1847) & Eut a & 8.93 & $0.390 \pm 0.014$ & 65 & 576.97 & 12 \\
\hline Harpacticus littoralis (Sars, 1910) & Harl & 3.42 & $0.320 \pm 0.014$ & 75 & 221.45 & 11 \\
\hline Tisbe battagliai (Volkmann-Rocco, 1972) & Tis & 13.00 & $1.400 \pm 0.090$ & 95 & 840.12 & 6 \\
\hline \multicolumn{7}{|l|}{ Cyclopoids } \\
\hline Oithona brevicornis (Giesbrecht, 1891) & Oit br & 1.06 & $0.650 \pm 0.156$ & 95 & 68.45 & 4 \\
\hline Oithona nana (Giesbrecht, 1892) & Oit $n$ & 14.87 & $0.560 \pm 0.041$ & 95 & 961.05 & 10 \\
\hline Oithona plumifera (Baird, 1843) & Oit pl & 7.49 & $1.410 \pm 0.034$ & 95 & 483.79 & 6 \\
\hline Oithona similis (Claus, 1866) & Oit $s$ & 4.27 & $0.410 \pm 0.037$ & 90 & 276.30 & 7 \\
\hline Oithona sp. (Baird, 1843) & Oit sp. & 5.11 & $0.880 \pm 0.071$ & 100 & 330.68 & 6 \\
\hline \multicolumn{7}{|l|}{ Poecilostomatoids } \\
\hline Oncaea mediterranea (Claus, 1863) & Onc m & 0.93 & $0.650 \pm 0.003$ & 65 & 60.27 & 7 \\
\hline Oncaea minuta (Giesbrecht, 1892) & Onc mi & 0.23 & $0.620 \pm 0.006$ & 60 & 14.88 & 3 \\
\hline Triconia conifera (Giesbrecht, 1891) & Tri & 0.26 & $0.650 \pm 0.006$ & 70 & 16.87 & 19 \\
\hline Corycaeus clausi (Dahl, 1894) & Cor cl & 1.14 & $1.210 \pm 0.035$ & 90 & 73.56 & 16 \\
\hline Corycaeus latus (Dana, 1849) & Cor la & 0.38 & $0.690 \pm 0.007$ & 85 & 24.40 & 5 \\
\hline Corycaeus speciosus (Dana, 1849) & Cor sp & 0.05 & $0.800 \pm 0.029$ & 90 & 300.20 & 5 \\
\hline Large copepods (1.45-2.5 mm) & & 7.26 & & & & \\
\hline \multicolumn{7}{|l|}{ Calanoids } \\
\hline Calanus helgolandicus (Claus, 1863) & Cal h & 7.23 & $1.780 \pm 0.047$ & 90 & 467.69 & 6 \\
\hline Temora stylifera (Dana, 1849) & Tem $s$ & 0.03 & $1.490 \pm 0.008$ & 30 & 1.84 & 11 \\
\hline \multicolumn{7}{|l|}{ Miscellaneous zooplankton (27\%) } \\
\hline Meroplankton & & 81 & & & & \\
\hline Polychaeta larvae & Pla & 18.36 & $0.612 \pm 0.011$ & 95 & 564.34 & 10 \\
\hline Cirripedia larvae & Cla & 16.46 & $0.766 \pm 0.015$ & 90 & 505.69 & 10 \\
\hline Ostracoda & Ost & 1.30 & $0.502 \pm 0.001$ & 15 & 40.05 & 6 \\
\hline Medusa & Med & 0.61 & $0.120 \pm 0.001$ & 50 & 18.61 & 10 \\
\hline Zoea & Zoe & 0.50 & $0.402 \pm 0.002$ & 55 & 15.21 & 5 \\
\hline Fish eggs & Egg & 43.64 & $0.510 \pm 0.005$ & 100 & 1341.06 & 10 \\
\hline Holoplankton & & 19 & & & & \\
\hline Appendicularia & App & 16.12 & $1.025 \pm 0.004$ & 100 & 495.30 & 10 \\
\hline Cladocera & Cla & 0.12 & $0.515 \pm 0.003$ & 35 & 3.75 & 18 \\
\hline Foraminifera & For & 2.90 & $0.306 \pm 0.006$ & 70 & 89.06 & 10 \\
\hline
\end{tabular}

between 0.03 bits individual $^{-1}$ (14 species, S6) and 2.42 bits individual $^{-1}$ (26 species, S17; Fig. $2 m, n$ ).

There were significant differences between the groups of stations in the two zones (northern $v$. southern) for several environmental parameters. Water temperature, turbidity and COD were significantly higher in the northern than southern stations, whereas salinity and $\mathrm{pH}$ were higher in southern than northern stations. However, there were no significant differences for most zooplankton parameters between the northern and southern stations, except for total copepods, cyclopoids and total adult females, which were more abundant in the northern than southern stations. However, the number of copepod species, the Shannon-Wiener index $\left(H^{\prime}\right)$ and the dominance index $(\delta)$ were higher in the southern than northern stations (Student's $t$-test, $P<0.05$; Table 1). There was a tendency for $\delta$ to decrease from onshore to offshore stations (Fig. 3). 


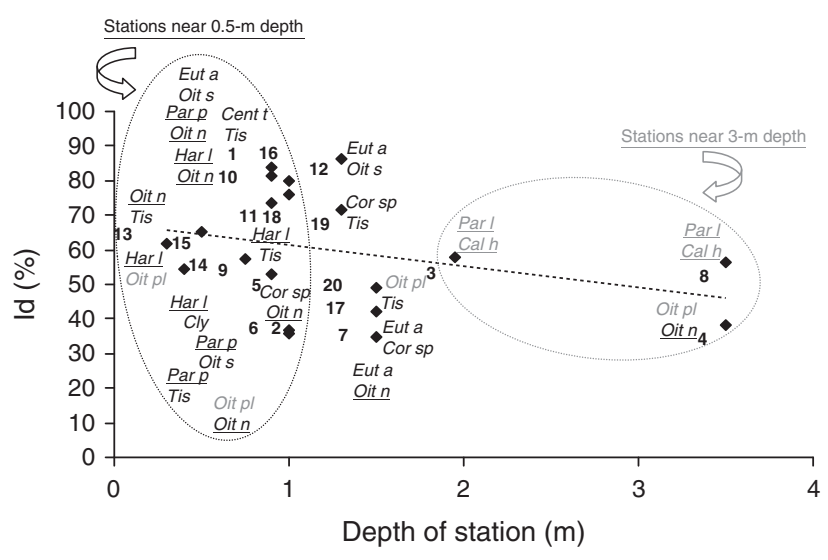

Fig. 3. Relationships between the dominance index of the planktonic copepod species and station depth off the southern coast of Sfax in spring (March 2013). Cal h, Calanus helgolandicus; Cen t, Centropages typicus; Cly, Clytemnestra scutellata; Cor sp, Corycaeus speciosus; Eut a, Euterpina acutifrons; Har l, Harpacticus littorallis; Oit pl, Oithona plumifera; Oit s, Oithona similis; Par l, Paracartia latisetosa; Par p, Paracalanus parvus Tis, Tisbe battagliai; Oit n, Oithona nana. Numbers next to diamonds indicate station numbers, dominant species in 'coastal' areas (stations near $0.5-\mathrm{m}$ depth) are in black and underlined text, in 'intermediate' areas (stations $0.5-3-\mathrm{m}$ depth) are in light grey, in 'offshore' areas (stations near $3-\mathrm{m}$ depth) are in light grey and underlined, and the rest of species are in black text.

The coastal area (stations of $\sim 0.5-\mathrm{m}$ depth; southern stations exclusively; S11, S13-15) was characterised by 25 small planktonic copepod species $(<1.45 \mathrm{~mm})$ contributing to $93 \%$ of total copepod abundance, namely $O$. nana $(14 \%), P$. parvus $(14 \%)$ and H. littoralis (3.5\%; Fig. 3; Table 2). However, P. latisetosa $(<1.45 \mathrm{~mm} ; 6.5 \%)$ and C. helgolandicus $(1.45-2.5 \mathrm{~mm} ; 7.5 \%)$ were exclusively dominant at depths of $\sim 3 \mathrm{~m}$ (northern stations exclusively; S3, S4 and S8). O. plumifera $(<1.45 \mathrm{~mm} ; 7.5 \%)$ was found in substantial amounts at depths between 0.5 and $3 \mathrm{~m}$ (Fig. 3; Table 2). Two larger copepods (1.45-2.5 mm), namely C. helgolandicus $(1.780 \pm 0.047 \mathrm{~mm})$ and Temora stylifera $(1.490 \pm 0.008 \mathrm{~mm})$, were identified in the samples (T. stylifera in S14; C. helgolandicus in S3 and S8) and accounted for 7.3\% of total copepod abundance (Fig. 3; Table 2).

\section{Factors regulating spatial distribution of copepod assemblages}

The first factorial plane of the co-inertia analysis explained $69 \%$ of the variance, of which $51 \%$ was attributed to the first axis and $18 \%$ to the second. Therefore, the co-inertia analysis demonstrated a co-structure between the two datasets (i.e. copepod abundance and environmental-trophic variables). The correlation between the environmental and biological coordinates of the stations on the first factorial plane, reflecting the degree of association between the environmental and copepod systems, was highly significant, with $R$-values of 0.76 and 0.73 for the two factorial planes (Axis F1 environment/Axis F1 biology and Axis F2 environment/Axis $\mathrm{F}_{2}$ biology respectively; Fig. $4 c, d$ ). In both the 'environment' and 'copepod' structures, Axis 1 showed a distinction between northern stations ( $\mathrm{S} 1-10$, except S2) and southern stations (S11-20; Fig. 4c). Northern stations were characterised by higher depth, turbidity, COD and phosphorus $\left(\mathrm{PO}_{4}{ }^{3-}\right.$ and total $\left.\mathrm{P}\right)$ and lower taxonomic diversity. Northern stations were also associated with several copepod taxa (P. latisetosa, C. helgolandicus, $P$. parvus, Centropages typicus and several Oithona species; Fig. $4 a, b)$, including the smallest copepod species, such as $O$. nana (14\%; $0.560 \pm 0.041 \mathrm{~mm})$ and $P$. parvus $(14 \% ; 1.010 \pm 0.005 \mathrm{~mm})$. These species were associated with a high COD level, as indicated by the significant positive correlations $(r=0.38-0.50$; $P<0.05)$.

Southern stations were characterised by high salinity, $\mathrm{pH}$, $\mathrm{NO}_{3}{ }^{-}$and $\mathrm{N} / \mathrm{P}$ ratio relative to the northern stations, and were associated with other copepod taxa, namely Acartidae (Acartia clausi, Acartia danae, Acartia longiremi, Paracartia grani), Triconia conifera, Oncaea minuta, T. stylifera, Corycaeus latus, $C$. clausi and H. littoralis (Fig. 4a,b), including large copepod species such as $T$. stylifera $(0.03 \% ; 1.490 \pm 0.008 \mathrm{~mm})$. The association of these latter copepod species with high SPM and low $\mathrm{COD}$, total $\mathrm{P}$ and $\mathrm{PO}_{4}{ }^{3-}$ was particularly strong for stations situated in the last transect (S17-20) in front of Hakmouni wadi, removing the release of the olive oil wastes from margins and the phosphate industry releases to the sea, which was a source of pollutant discharge from the phosphogypsum wastes issued from the SIAPE manufactory and the olive oil wastes from margins. On the second axes of the two systems, in contrast with the other stations, S10 and S13 were characterised by high Si $(\mathrm{OH})_{4}$ concentrations and by the presence of Clytemnestra scutellata.

\section{Discussion}

Sfax (733 687 inhabitants) is a site of intense maritime, urban and industrial activities that contribute to the degradation of coastal water quality (Ben Salem et al. 2015; Drira et al. 2016). In the southern coastal area, the major sources of pollution include urban, industrial and municipal wastewaters, the fishing harbor and waste-processing phosphates (Ben Abdallah et al. 2006; Aloulou et al. 2012; Choura et al. 2015). Previously, this area was thoroughly characterised with regard to physicochemical and biogeochemical analyses of the surface waters (Drira et al. 2016). In the present study, we focused on copepods that, according to Rajagopal et al. (2011) and Ekpo (2013), play an integral role and serve as bioindicators of water pollution (Mukhopadhyay et al. 2000). Indeed, species variation, distribution and abundance of zooplankton highly depend on the chemical and physical properties of water (Patra et al. 2011). The species diversity index is a relevant tool for water quality assessment and a basis for biomonitoring by evaluating the structural complexity of zooplankton assemblages (Jafari et al. 2011; Patra et al. 2011). In the present study, the ShannonWiener index $\left(H^{\prime}\right)$ for copepods was fairly low: $H^{\prime}$ was $<1.5$ bits individual $^{-1}$ for $55 \%$ of stations, including most northern stations (S1-10), except S3, S5 and S10, which had pioneer communities at the colonisation stage, and ranging between 1.5 and 2.5 bits individual $^{-1}$ for the other stations, demonstrating a transition ecosystem at the diversification stage (Shannon and Weaver 1963). According to Wilhm (1975) and Mukhopadhyay et al. (2007), a high $H^{\prime}$ suggests rich diversity and therefore a healthier (less polluted) ecosystem, whereas a low $H^{\prime}$ indicates 

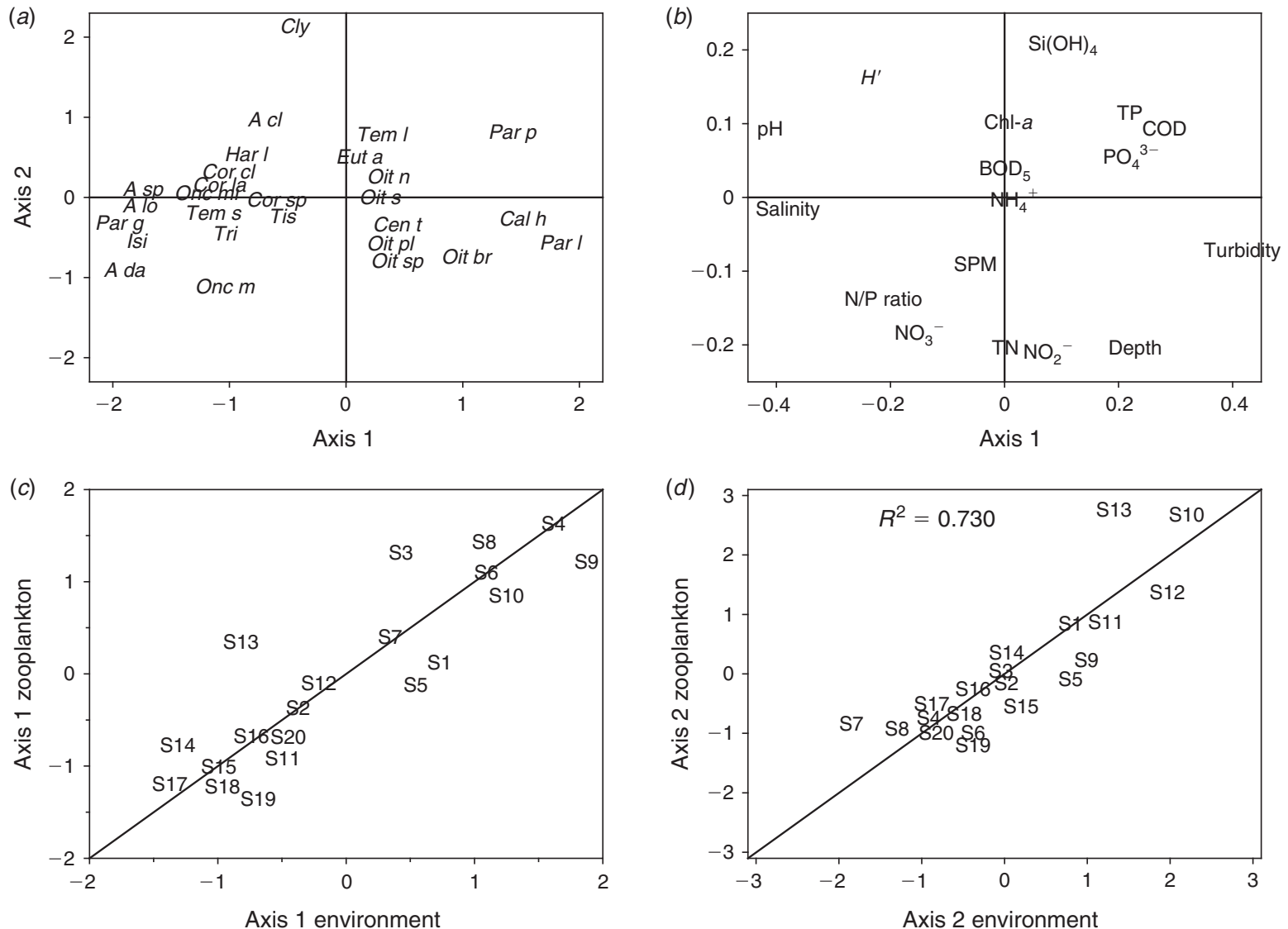

Fig. 4. Co-inertia analysis. Ordination on the axes $(1,2)$ of $(a)$ copepod taxa and $(b)$ environmental variables and plots of the sampling points on the $(c)$ first and $(d)$ axes second of the two systems. The diagonal lines represent equality between the coordinates on the two systems. (a) Symbols used to indicate taxa are defined in Table 2. S1-20, Stations 1-20; Chl- $a$, chlorophyll- $a$; $H^{\prime}$, Shannon-Wiener diversity index; TP, total P; TN, total N; BOD $_{5}$, 5-day biochemical oxygen demand; SPM, suspended particulate matter; COD, chemical oxygen demand.

poor diversity. Quite low $H^{\prime}$ values for copepod communities $\left(0.48-0.89\right.$ bits individual $\left.^{-1}\right)$ were reported in 2008 in the same area (Ben Salem et al. 2015). In contrast, the Sfax northern coast (north of the commercial harbour), partly rehabilitated through the TaparuraProject (including confinement of phosphogypsum and depollution of coastal waters; Callaert et al. 2009), was characterised by much higher $H^{\prime}$ values in the same season (most values $>2$ bits individual ${ }^{-1}$, with a maximum of 3.5 bits individual $^{-1}$; Rekik et al. 2012). Note the difference in $H^{\prime}$ between the southern (present study) and northern (investigated by Rekik et al. 2012) coasts in the same season, spring, after the rehabilitation process through the TaparuraProject. The nutrient $\left(\mathrm{NO}_{3}{ }^{-}\right.$and $\left.\mathrm{PO}_{4}{ }^{3-}\right)$ concentrations in the present study are considerably (2- and 20-fold respectively) higher than those reported by Rekik et al. (2012). Indeed, high nutrient inputs in a mesotrophic system hinder the stability of the ecosystem, thus leading to a reduction in species richness (Bell 2005; Ben Salem et al. 2015). In the present study, with regard to $H^{\prime}$ values, we may also consider that the water quality in the northern zone of the study area $\left(H^{\prime}=0.75 \pm 0.89\right)$ was substantially degraded compared with that in the southern zone $\left(H^{\prime}=1.54 \pm 0.63\right)$, less affected by the sewage from El Maou wadi, the phosphate industry and WWTP, even though nutrient concentrations were not significantly different between the two zones (Student's $t$-test, $P>0.05$ ).

The difference in copepod biodiversity between the northern (S1-10) and southern (S11-20) stations could be explained, in part, by the spatial distribution of dissolved trace metals. Indeed, Ben Salem and Ayadi (2016) showed that the highest contents of dissolved $\mathrm{Cd}\left(0.21 \mu \mathrm{g} \mathrm{L}^{-1}\right), \mathrm{Cu}\left(4.34 \mu \mathrm{g} \mathrm{L}^{-1}\right), \mathrm{Fe}$ (30.74 $\left.\mu \mathrm{g} \mathrm{L}^{-1}\right)$, Ni (10.21 $\left.\mu \mathrm{g} \mathrm{L}^{-1}\right), \mathrm{Pb}\left(3.43 \mu \mathrm{g} \mathrm{L}^{-1}\right)$ and $\mathrm{Zn}$ $\left(5.78 \mu \mathrm{g} \mathrm{L}^{-1}\right)$ were found in stations situated in front of the WWTP (i.e. S9 in the present study). The $\mathrm{Cu}$ and Ni concentrations exceeded the continuous concentration and maximum concentrationin the USEnvironmental Protection Agency water quality criteria (US Environmental Protection Agency 1999).

COD was more important in the northern than southern stations (Drira et al. 2016). The highest values were recorded at S9, located in front of the phosphate industry plant, which releases large amounts of $\mathrm{PO}_{4}{ }^{3-}, \mathrm{Cl}^{-}$and $\mathrm{SO}_{4}{ }^{2-}$ into the sea (Drira et al. 2016). Inputs of phosphates and organic matter may contribute to the increase in $\mathrm{COD}, \mathrm{BOD}_{5}$ and $\mathrm{SPM}$ in surface waters (Davis and Marshall 1998; Negi and Rajput 2013; Drira et al. 2016) and subsequently to changes in the community structure of zooplankton (Tallberg et al. 1999; Arora and Mehra 2009). In the present study, a $\mathrm{BOD}_{5} / \mathrm{COD}$ ratio $<0.5$ indicates 
pollution of a chemical origin (Ohwoghere-Asuma and Aweto 2013; El Rhaouat et al. 2014; Jamwal et al. 2015) whereas COD/ $\mathrm{BOD}_{5}$ ratios $>3$ indicate an organic load of a low biodegradability (Drira et al. 2016). In addition, the highest density of copepods $\left(35.85 \times 10^{3}\right.$ individuals $\mathrm{m}^{-3}$; S6) was associated with a high $\mathrm{BOD}_{5}\left(60 \mathrm{mg} \mathrm{L}^{-1}\right) . \mathrm{BOD}_{5}$ is a key parameter that regulates the population of copepods (Jagadeeshappa and Kumara 2013). The increase in the total numerical density of zooplankton has been shown to be related to a decrease in SPM load (Bhattacharya et al. 2014). The same result was found in the present study for S10, which had the highest zooplankton density $\left(47.95 \times 10^{3}\right.$ individuals $\left.\mathrm{m}^{-3}\right)$ and the lowest SPM $\left(17.9 \mathrm{mg} \mathrm{L}^{-1}\right)$.

The present study showed that there were more adult females than males. Several studies have shown that pollution may affect the population dynamics of zooplankton species by controlling individual survival and reproduction, and by altering the sex ratio. For example, Medina et al. (2002) reported that adult males of Acartia tonsa were much more sensitive than females to contamination by pyrethroids. This is consistent with the results of the present study showing a preponderance of females and thus suggesting a high mortality of males in a highly polluted environment. The preponderance of females over males, which reduces the sexratio (Kiørboe 2006), may be due to the higher mortality of males because of their increased vulnerability to predation during their search for mates (Mendes-Gusmão et al. 2013). However environmental factors driving differential physiological longevity of males and females may be more important in determining the sex ratio (Mendes-Gusmão et al. 2013). Comparisons of the size structure and composition of zooplankters can indicate the nature and extent of pollutant loads (Sarma 1996; Mukhopadhyay et al. 2000). In the present samples, dominant species such as $O$. nana, P. parvus, H. littoralis and T. battagliai were spread in the shallow waters $(\sim 0.5-\mathrm{m}$ depth) along the coast and thus appeared more adapted to the coastal anthropogenic inputs. In addition, the small cyclopoid $O$. nana had clear eurythermal and euryhaline distributions (Drira et al. 2014). Nonetheless, large copepods $(>1.45 \mathrm{~mm})$, such as $C$. helgolandicus (relative abundance $7.23 \%$, total length $1.78 \pm 0.05 \mathrm{~mm}$ ) dominated in the more off-shore zone at $\sim 3-\mathrm{m}$ depth. The coastal anthropogenic inputs affected the copepod species by decreasing their body size. O. plumifera, a small copepod species $(<1.45 \mathrm{~mm}$; $7.5 \%$ ), was found in substantial amounts between the inshore and offshore areas. Copepod species can be classified into different ecological groups based on water quality affinities (Hooff and Peterson 2006; Bi et al. 2012). In the present study, we identified three different groups that are good indicators of water pollution, as discussed below.

The first group is composed of $O$. nana $(14.9 \%$ of the total adult copepod count), P. parvus (14\%) and H. littoralis $(3.4 \%)$, which were the dominant small $(<1.45 \mathrm{~mm})$ copepod species. These species were spread along the coast, proliferated primarily in shallow waters $(\sim 0.5-\mathrm{m}$ depth $)$ and were thus better adapted than other species to coastal anthropogenic inputs. These species are resistant to unfavourable conditions and have a high capacity to develop in eutrophicated and polluted areas (Arfi et al. 1981). O. nana was reported to be dominant in the Gulf of Gabes (Drira et al. 2014) and in the Tunis North Lagoon (Annabi-Trabelsi et al. 2005), accounting for 87 and
$31 \%$ of total copepod abundance respectively. Several studies have demonstrated that $O$. nana, which has a certain ability to endure environmental perturbations because of its low respiratory rate and omnivorous diet (Gallienne and Robins 2001; Rekik et al. 2013b; Ben Ltaief et al. 2015), is able to proliferate in unstable ecosystems and capable of colonising polluted environments (Williams and Muxagata 2006; Drira et al. 2010 , 2014; Rekik et al. 2013 b) and areas subjected to eutrophication (Richard and Jamet 2001). A possible link between phosphate and the abundance of $O$. nana in the Gulf of Gabes, and along the southern coast of Sfax in particular, was demonstrated in previous studies (Drira et al. 2010, 2014; Ben Salem et al. 2015). Thus, this species is cosmopolitan in many marine ecosystems (Fernández de Puelles et al. 2007) and dominant in coastal areas of several Mediterranean regions (Mazzocchi and Ribera d'Alcala 1995; Christou 1998), including the Algerian basin (Gaudy 1985; Riandey et al. 2005). Tolerance to pollution, as observed in the Gulf of Gabes, may also explain the high proliferation of $O$. nana observed in the Bay of Toulon (north-western Mediterranean) by Jamet et al. (2001), who suggested that this species may be used as a biological indicator of such unhealthy systems.

The second group of good indicators of water pollution consists of $P$. latisetosa $(<1.45 \mathrm{~mm})$ and $C$. helgolandicus $(7.5 \% ; 1.45-2.5 \mathrm{~mm})$, which were dominant only in waters of $\sim 3$-m depth (northern stations exclusively; i.e. S3, S4 and S8). The large copepod C. helgolandicus is rare in inshore waters, with maximum abundance in the present study observed in offshore waters, as reported for the Irish Sea (Gowen et al. 1999) and the Mediterranean Sea (Zakaria et al. 2016).

The third group is represented by $O$. plumifera $(<1.45 \mathrm{~mm}$; $7.5 \%$ ), which was found in substantial amounts at depths between 0.5 and $3 \mathrm{~m}$ (Fig. 3; Table 2). O. plumifera was shown to be the most abundant component of coastal and oceanic copepod assemblages in shallow nearshore waters off the southern coast of South Africa $\left(6 \times 10^{3}\right.$ individuals $\mathrm{m}^{-3}$; Porri et al. 2007). This species exhibits very particular swimming and feeding behaviour (Paffenhöfer and Mazzocchi 2002), allowing it to exploit the large variety of available food resources, such as phytoplankton, ciliates and detritus (Ribera d'Alcalà et al. 2004). A perusal of literature has shown that this species is tolerant of organic pollution, which may favour its dominance when COD values are high (Bhattacharya et al. 2014).

Along the Sfax southern coast, anthropogenic inputs as well as tidal and current conditions may explain the high level of organic debris preferentially consumed by $O$. plumifera. Furthermore, it was demonstrated that suspended matter was homogeneously distributed in neritic and open sea in the Gulf of Gabes (Drira et al. 2010). In summary, the present study demonstrates that the nearshore coastal waters appear to be more responsive or sensitive to anthropogenic inputs, resulting in the different copepod species assemblages.

\section{Conclusions}

Zooplankton composition may reflect water quality in coastal marine ecosystems. The present study was undertaken to assess zooplankton species diversity in relation to anthropogenic inputs along the southern coastline of Sfax. Copepod 
assemblages could move along the tides and currents, which may partially mask the effects of water chemistry (anthropogenic inputs) on zooplankton diversity and composition. The results of the present study revealed that the most abundant mesozooplankton copepod species (O. nana, P. parvus, H. littoralis and T. battagliai) were spread along the coast and were more adapted and tolerant of coastal anthropogenic inputs. The copepod diversity was higher in the southern, less-affected stations $\left(H^{\prime}\right.$ between 1.5 and 2.5 bits individual $\left.{ }^{-1}\right)$ than in the northern stations, which were more affected by sewage $\left(H^{\prime} \leq\right.$ 1.5 bits individual $^{-1}$ ). In addition, a shift in the planktonic copepod community between the two zones was linked to a deterioration in water quality (high phosphorus content, high turbidity, high COD) in the northern zone directly subjected to higher levels of pollutant discharge. Increased nutrient loading from expanding anthropogenic activities along the southern coast of Sfax must be carefully considered in order to maintain the stability of the ecosystem and increase plankton richness. Therefore, integrated management of the southern coast of Sfax remains an important need and public awareness is required to improve the water quality and biodiversity in the region.

\section{Conflicts of interest}

The authors declare that they have no conflicts of interest.

\section{Acknowledgments}

This work was supported by the 'Sfax Integrated Coastal Area Management Tunisia' (SMAP III) project, conducted in the Biodiversity and Aquatic Ecosystems UR/11ES72 Research Unit at the University of Sfax in collaboration with the Mediterranean Institute of Oceanography (MIO) Marseille, France, and the Research Institute for Development (IRD) French-Tunisian International Joint Laboratory 'LMI COSYS-Med'. The authors thank the Société d'études et d'Aménagement des Côtes Nord de la ville de Sfax (SEACNVS) for providing access to the sampling site. This study was performed within the framework of the postdoctoral fellowship of Zaher Drira (University of Sfax). The authors acknowledge Mr Tarek Omar and Mr Hammouda Sahnoun for their technical help during the cruise. Two anonymous reviewers and the Handling Editor are acknowledged for their relevant comments and corrections. The authors are equally grateful to Mr Kamel Maaloul, translator and English professor, for proofreading the manuscript.

\section{References}

Aloulou, F., Elleuch, B., and Kallel, M. (2012). Benthic foraminiferal assemblages as pollution proxies in the northern coast of Gabes Gulf, Tunisia. Environmental Monitoring and Assessment 184, 777-795. doi:10.1007/S10661-011-2001-2

Annabi-Trabelsi, N., Daly-Yahia, M. N., Romdhane, M. S., and Ben Maïz, N. (2005). Seasonal variability of planktonic copepods in Tunis North lagoon (Tunisia, North Africa). Cahiers de Biologie Marine 46, 325-333.

Arfi, R., Champalbert, G., and Patriti, G. (1981). Système planctonique et pollution urbaine: un aspect des populations zooplanctoniques. Marine Biology 61, 133-141. doi:10.1007/BF00386652

Arora, J., and Mehra, N. K. (2009). Seasonal dynamics of zooplankton in a shallow eutrophic, man-made hyposaline lake in Delhi (India): role of environmental factors. Hydrobiologia 626, 27-40. doi:10.1007/S10750009-9735-7

Barhoumi, S., Messaoudi, I., Deli, T., Saïd, K., and Kerkeni, A. (2009). Cadmium bioaccumulation in three benthic fish species, Salaria basilisca, Zosterisessor ophiocephalus and Solea vulgaris collected from the Gulf of Gabes in Tunisia. Journal of Environmental Sciences 21, 980-984. doi:10.1016/S1001-0742(08)62371-2
Bell, G. (2005). The co-distribution of species in relation to the neutral theory of community ecology. Ecology 86, 1757-1770. doi:10.1890/04-1028

Ben Abdallah, F., Elloumi, N., Mezghani, I., Boukhris, M., and Garrec, J. P. (2006). Survival strategies of pomegranate and almond trees in a fluoride polluted area. Comptes Rendus Biologies 329, 200-207. doi:10.1016/ J.CRVI.2005.12.003

Ben Brahim, M., Hamza, A., Hannachi, I., Rebai, A., Jarboui, O., Bouain, A., and Aleya, L. (2010). Variability in the structure of epiphytic assemblages of Posidonia oceanica in relation to human interferences in the Gulf of Gabes, Tunisia. Marine Environmental Research 70, 411-421. doi:10.1016/J.MARENVRES.2010.08.005

Ben Ltaief, T., Drira, Z., Hannachi, I., Bel Hassen, M., Hamza, A., Pagano, M., and Ayadi, H. (2015). What are the factors leading to the success of small planktonic copepods in the Gulf of Gabes, Tunisia? Journal of the Marine Biological Association of the United Kingdom 95, 747-761. doi:10.1017/S0025315414001507

Ben Salem, Z., and Ayadi, H. (2016). Heavy metal accumulation in Diplodus annularis, Liza aurata, and Solea vulgaris relevant to their concentration in water and sediment from the southwestern Mediterranean (coast of Sfax). Environmental Science and Pollution Research International 23, 13895-13906. doi:10.1007/S11356-016-6531-6

Ben Salem, Z., Drira, Z., and Ayadi, H. (2015). What factors drive the variations of phytoplankton, ciliate and mesozooplankton communities in the polluted southern coast of Sfax, Tunisia? Environmental Science and Pollution Research International 22, 11764-11780. doi:10.1007/ S11356-015-4416-8

Bhattacharya, B. D., Bhattacharya, A., Rakshit, D., and Sarkar, S. K. (2014). Impact of the tropical cyclonic storm 'Aila' on the water quality characteristics and mesozooplankton community structure of Sundarban mangrove wetland. Indian Journal of Geo-Marine Science 43, 216-223.

Bi, H., Peterson, W. T., Peterson, J. O., and Fisher, J. L. (2012). A comparative analysis of coastal and shelf-slope copepod communities in the northern California Current system: synchronized response to large-scale forcing? Limnology and Oceanography 57, 1467-1478. doi: $10.4319 /$ LO.2012.57.5.1467

Biswas, M. (2015). Seasonal abundance of zooplankton in relation to physicochemical features in Rabindra Sarobar, Kolkata. International Research Journal of Interdisciplinary and Multidisciplinary Studies 1, 56-62.

Bradford-Grieve, J. M. (1999). ICES identification leaflets for plankton. Leaflet number 181 to replace Fiches d'ldentification du Zooplancton number 12. In 'Copepoda. Sub-Order: Calanoida, Family: Acartiidae, Genera: Acartia, Paracartia, Pteriacartia'. (Ed. J. A. Lindley.) pp. 1-19. (Natural Environment Research Council, Plymouth Marine Laboratory: Plymouth, UK.)

Callaert, B., Van Den Bogaert, J., Pieters, A., Pynaert, K., Tison, P., Levrau, K., Vander Heyde, D., and Glaser, D. (2009). Taparura Project: sustainable coastal development, including the decontamination and rehabilitation of the coastal area of the city of Sfax, Tunisia. In 'Best Environmental Practices in Coastal and Maritime Engineering, Proceedings of the First Coastal and Maritime Mediterranean Conference', 2009, Hammamet, Tunisia. (Eds D. Levacher, M. Sanchez, and E. Garry.) pp. 175-178. (Centre Français du Littoral.) Available at http://www. paralia.fr/cmcm/e01-44.pdf [Verified 14 September 2017].

Choura, M., Keskes, M., Chaari, D., and Ayadi, H. (2015). Study of the mechanical strength and leaching behavior of phosphogypsum in a sulfur concrete matrix. IOSR Journal of Environmental Science, Toxicology and Food Technology 9, 8-13. doi:10.9790/2402-09430813

Christou, E. D. (1998). Interannual variability of copepods in a Mediterranean coastal area (Saronikos Gulf, Aegean Sea). Journal of Marine Systems 15, 523-532. doi:10.1016/S0924-7963(97)00080-8

Costanzo, G., Campolmi, M., and Zagani, G. (2000). Stephos marsalensis new species (Copepoda, Calanoida, Stephidae) from coastal waters of Sicily, Italy. Journal of Plankton Research 22, 2007-2014. doi:10.1093/ PLANKT/22.10.2007 
Davis, L. N., and Marshall, H. G. (1998). Mesozooplankbon distribution and abundance in the Pagan River: a nutrient enriched subestuary of the James River, Virginia. Virginia Journal of Science 49, 151-162.

Dodson, S. (1992). Predicting crustacean zooplankton species richness. Limnology and Oceanography 37, 848-856. doi:10.4319/LO.1992.37. 4.0848

Dolédec, S., and Chessel, D. (1994). Co-inertia analysis: an alternative method for studying species environment relationships. Freshwater Biology 31, 277-294. doi:10.1111/J.1365-2427.1994.TB01741.X

Drira, Z., Bel Hassen, M., Ayadi, H., Hamza, A., Zarrad, R., Bouaïn, A., and Aleya, L. (2010). Copepod community structure related to environmental factors from a summer cruise in the Gulf of Gabes (Tunisia, eastern Mediterranean Sea). Journal of the Marine Biological Association of the United Kingdom 90, 145-157. doi:10.1017/S0025315409990403

Drira, Z., Bel Hassen, M., Ayadi, H., and Aleya, L. (2014). What factors drive copepod community distribution in the Gulf of Gabes, eastern Mediterranean Sea? Environmental Science and Pollution Research International 21, 2918-2934. doi:10.1007/S11356-013-2250-4

Drira, Z., Kmiha-Megdiche, S., Sahnoun, H., Hammami, A., Allouche, N., Tedetti, M., and Ayadi, H. (2016). Assessment of anthropogenic inputs in the surface waters of the southern coastal area of Sfax during spring (Tunisia, Southern Mediterranean Sea). Marine Pollution Bulletin 104, 355-363. doi:10.1016/J.MARPOLBUL.2016.01.035

Ekpo, I. (2013). Effect of physico-chemical parameters on zooplankton species and density of a tropical rainforest river in Niger Delta, Nigeria using canonical cluster analysis. International Journal of Engineering Science 2, 13-21.

El Rhaouat, O., El Kherrati, I., El Khayyat, F., Chiguer, H., Ezziani, K., Ibeda, A., Fareh, M., Saidi, Y., El Kharim, K., and Belghyti, D. (2014). Physico-chemical evaluation of urban wastewater of the town of Sidi Kacem. Computational Water, Energy, and Environmental Engineering 3, 30-35. doi:10.4236/CWEEE.2014.31004

Fernández de Puelles, M. L., Alemany, F., and Jansá, J. (2007). Zooplankton time series in the Balearic Sea (western Mediterranean): variability during the decade 1994-2003. Progress in Oceanography 74, 329-354. doi:10.1016/J.POCEAN.2007.04.009

Gallienne, C. P., and Robins, D. B. (2001). Is Oithona the most important copepod in the world's oceans? Journal of Plankton Research 23, 1421-1432. doi:10.1093/PLANKT/23.12.1421

Gang, R. K., Saksena, D. N., and Rao, R. J. (2006). Assessment of physicochemical water quality of Harsi reservoir, District Gwalior, Madhya Pradesh. Journal of Ecophysiology and Occupational Health 6, 33-40.

Gargouri, T. (2006). Diagnostic de la zone côtière sud du Grand Sfax, Projet SMAP III - Sfax. Rapport de synthèse global et Plan Directeur de Gestion Intégrée provisoire, Diagnostic Zone Côtière Sud du Grand Sfax étendue aux Îles Kerkennah Décembre 2006 Mai 2007, Special Publication Number 3, Expert/consultant ANPE (Agence Nationale de Protection de l'Environnement Tunisie) Municipalité de Sfax, Sfax, Tunisia.

Gaudy, R. (1985). Features and pecularities of zooplankton communities from the western Mediterranean. In 'Mediterranean Marine Ecosystems'. (Eds M. Moraitou and V. Kiortsis.) pp. 279-301. (Plenum Press: New York, NY, USA.)

Gowen, R. J., McCullough, G., Kleppel, G. S., Houchin, L., and Elliott, P. (1999). Are copepods important grazers of the spring bloom in the western Irish Sea? Journal of Plankton Research 21, 465-483. doi:10.1093/PLANKT/21.3.465

Hooff, R. C., and Peterson, W. T. (2006). Copepod biodiversity as an indicator of changes in ocean and climate conditions of the northern California current ecosystem. Limnology and Oceanography 51, 2607-2620. doi:10.4319/LO.2006.51.6.2607

Jafari, N., Nabavi, S. M., and Akhavan, M. (2011). Ecological investigation of zooplankton abundance in the river Haraz, northeast Iran: impact of environmental variables. Archives of Biological Sciences 63, 785-798. doi: $10.2298 / \mathrm{ABS} 1103785 \mathrm{~J}$
Jagadeeshappa, K. C., and Kumara, V. (2013). Influence of physicochemical parameters on the diversity of plankton species in wetlands of Tiptur Taluk, Tumkur Dist, Karnataka State, India. Caribbean Journal of Science and Technology 1, 185-193.

Jamet, J. L., Boge, G., Richard, S., Geneys, C., and Jamet, D. (2001). The zooplankton community in bays of Toulon area (northwest Mediterranean Sea, France). Hydrobiologia 457, 155-165. doi:10.1023/ A: 1012279417451

Jamwal, P., Zuhail, T. M., Raje Urs, P., Srinivasan, V., and Lele, S. (2015). Contribution of sewage treatment to pollution abatement of urban streams. Current Science 108, 677-685.

Khwaja, S., Manish, V., Suresh, G., Chirag, G., Virendra, K. S., and Mohammad, D. H. (2014). Diel variations in limnological characteristics of Omkareshwar reservoir of Narmada River, India. Journal of Ecology and the Natural Environment 6, 12-24. doi:10.5897/JENE2013.0371

Kiørboe, T. (2006). Sex, sex-ratios and the dynamics of pelagic copepod populations. Oecologia 148, 40-50. doi:10.1007/S00442-005-0346-3

Kushwaha, V. B., and Agrahari, M. (2014). Effect of domestic sewage on zooplankton community in River Rapti at Gorakhpur, India. World Journal of Zoology 9, 86-92.

Madin, L. P., Horgan, E. F., and Steinberg, D. K. (2001). Zooplankton at the Bermuda Atlantic Time-series Study (BATS) station: diel, seasonal and interannual variation in biomass, 1994-1998. Deep-Sea Research 48 2063-2082. doi:10.1016/S0967-0645(00)00171-5

Mazzocchi, M. G., and Ribera d'Alcala, M. (1995). Recurrent patterns in zooplankton structure and succession in a variable coastal environment. ICES Journal of Marine Science 52, 679-691. doi:10.1016/1054-3139 (95)80081-6

Medina, M., Barata, C., Telfer, T., and Baird, D. (2002). Age and sex related variation in sensitivity to the pyrethroid cypermethrin in the marine copepod Acartia tonsa Dana. Archives of Environmental Contamination and Toxicology 42, 17-22. doi:10.1007/S002440010286

Mendes-Gusmão, L. F., McKinnon, A. D., and Richardson, A. J. (2013). No evidence of predation causing female-biased sex ratios in marine pelagic copepods. Marine Ecology Progress Series 482, 279-298. doi:10.3354/ MEPS 10265

Mezghani-Chaari, S., Hamza, A., and Hamza-Chaffai, A. (2011). Mercury contamination in human hair and some marine species from Sfax coasts of Tunisia: levels and risk assessment. Environmental Monitoring and Assessment 180, 477-487. doi:10.1007/S10661-010-1800-1

Mukhopadhyay, S. K., Chatterjee, A., Gupta, R., and Chattopadhyay, B. (2000). Rotiferan community structure of a tannery effluent stabilisation pond in east Calcutta wetland ecosystem. Chemical and Environmental Research 9, 85-91.

Mukhopadhyay, S. K., Chattopadhyay, B., Goswami, A. R., and Chatterjee, A. (2007). Spatial variations in zooplankton diversity in waters contaminated with composite effluents. Journal of Limnology $\mathbf{6 6}$ 97-106. doi:10.4081/JLIMNOL.2007.97

Negi, R. K., and Rajput, A. (2013). Impact of pulp and paper mill effluents on the diversity of zooplankton in the Ganga River water at Bijnor (UP) India. Journal of Biology 6, 112-117.

Ohwoghere-Asuma, O., and Aweto, K. E. (2013). Leachate characterization and assessment of groundwater and surface water qualities near municipal solid waste dump site in Effurun, Delta state, Nigeria. Journal of Environment and Earth Science 3, 126-134.

Paffenhöfer, G. A., and Mazzocchi, M. G. (2002). On some aspects of the behaviour of Oithona plumifera (Copepoda: Cyclopoida). Journal of Plankton Research 24, 129-135. doi:10.1093/PLANKT/24.2.129

Patra, A., Santra, K. B., and Manna, C. K. (2011). Ecology and diversity of zooplankton in relation to physico-chemical characteristics of water of Santragachi Jheel, West Bengal, India. Journal of Wetlands Ecology 5 20-39. doi:10.3126/JOWE.V5I0.4595

Porri, F., McQuaid, C. D., and Froneman, W. P. (2007). Spatio-temporal variability of small copepods (especially Oithona plumifera) in shallow 
nearshore waters off the southern coast of South Africa. Estuarine, Coastal and Shelf Science 72, 711-720. doi:10.1016/J.ECSS.2006.12.006

Rajagopal, T., Thangamani, A., Sevarkodiyone, S., Sekar, M., and Archunan, G. (2011). Zooplankton diversity and physico-chemical conditions in three perennial ponds of Virudhunagar district, Tamilnadu. Journal of Environmental Biology 31, 265-272.

Rekik, A., Drira, Z., Guermazi, W., Elloumi, J., Maalej, S., Aleya, L., and Ayadi, H. (2012). Impacts of an uncontrolled phosphogypsum dumpsite on summer distribution of phytoplankton, copepods and ciliates in relation to abiotic variables along the near shore of the southwestern Mediterranean coast. Marine Pollution Bulletin 64, 336-346. doi:10.1016/J.MARPOLBUL.2011.11.005

Rekik, A., Denis, M., Aleya, L., Maalej, S., and Ayadi, H. (2013a). Spring plankton community structure and distribution in the north and south coasts of Sfax (Tunisia) after north coast restoration. Marine Pollution Bulletin 67, 82-93. doi:10.1016/J.MARPOLBUL.2012.11.029

Rekik, A., Maalej, S., Ayadi, H., and Aleya, L. (2013b). Restoration impact of an uncontrolled phosphogypsum dump site on the seasonal distribution of abiotic variables, phytoplankton and zooplankton along the near shore of the south-western Mediterranean coast. Environmental Science and Pollution Research International 20, 3718-3734. doi:10.1007/ S11356-012-1297-Y

Riandey, V., Champalbert, G., Carlotti, F., Taupier-Letage, I., and ThibaultBotha, D. (2005). Zooplankton distribution related to the hydrodynamic features in the Algerian Basin (western Mediterranean Sea) in summer 1997. Deep-sea Research - I. Oceanographic Research Papers 52, 2029-2048. doi:10.1016/J.DSR.2005.06.004

Ribera d'Alcalà, M., Conversano, F., Corato, F., Licandro, P., Mangoni, O., Marino, D., Mazzocchi, M. G., Modigh, M., Montresor, M., Nardella, M., Saggiomo, V., Sarno, D., and Zingone, A. (2004). Seasonal patterns in plankton communities in a pluriannual time series at a coastal Mediterranean site (Gulf of Naples): an attempt to discern recurrences and trends. Scientia Marina 68, 65-83. doi:10.3989/SCIMAR.2004.68S165

Richard, S., and Jamet, J. (2001). An unusual distribution of Oithona nana Giesbrecht (1892) (Crustacea: Cyclopoida) in a bay: the case of Toulon Bay (France, Mediterranean Sea). Journal of Coastal Research 17, 957-963.

Rose, M. (1933). 'Copépodes pélagiques. Faune de la France, 26.' (Le Chevalier: Paris, France.)

Rosenberg, D. M., and Resh, V. H. (1993). 'Freshwater Biomonitoring and Benthic Macroinvertebrates.' (Chapman and Hall: New York, NY, USA.)

Sanyal, P., Bhattacharya, N., and Chakraborty, S. K. (2015). Biomonitoring of four contrasting wetlands of Kolkata, West Bengal based on zooplankton ecodynamics and biotic indices. Journal of Environmental Protection 6, 683-699. doi:10.4236/JEP.2015.67062

Sarma, S. S. S. (1996). Some relationships between size structure and fertility of rotifer populations. In 'Advances in Fish Wildlife Ecology and Biology'. (Ed. B. L. Kaul.) pp. 37-50. (Daya Publishing House: Delhi, India.)

Shannon, C. E., and Weaver, W. (1949). 'The Mathematical Theory of Communication.' (University of Illinois Press: Urbana, IL, USA.)
Shannon, C. E., and Weaver, W. (1963). 'The Mathematical Theory of Communication', 1st paperbound edition. (University of Illinois Press: Urbana, IL, USA.)

Sharma, B. K. (1998). Faunal diversity in India: Rotifera. In 'Faunal Diversity of India'. (Eds J. R. B Alfred, A. K. Das, and A. K. Sanyal.) pp. 57-70. (Environmental Centre, India, Zoological Survey of India: Calcutta, India.)

Shastri, Y. (2000). Physicochemical characteristics of River Mosem. Geobios 27, 194-196.

Sokal, R. R., and Rohlf, F. J. (1981). 'Biometry: The Principles and Practices of Statistics in Biological Research', 2nd edn. (W. H. Freeman and Co.: New York, NY, USA.)

Sundaresan, S., and Kumar, S. B. (2013). Seasonal variation and distribution of zooplanktonic fauna in Tandalam Pond (Chennai). International Journal of Pharmaceutical and Biological Archives 4, 727-730.

Tallberg, P., Horppila, J., Vaisanen, A., and Nurminen, L. (1999). Seasonal succession of phytoplankton and zooplankton along a trophic gradient in a eutrophic lake - implications for food web management. Hydrobiologia 412, 81-94. doi:10.1023/A:1003804417036

Tayibi, H., Choura, M., Lopez, F. A., Alguacil, F. J., and Lopez-Delgado, A. (2009). Environmental impact and management of phosphogypsum. Journal of Environmental Management 90, 2377-2386. doi:10.1016/ J.JENVMAN.2009.03.007

Thioulouse, J., Chessel, D., Dolédec, S., and Olivier, J. (1997). Ade-4: a multivariate analysis and graphical display software. Statistics and Computing 7, 75-83. doi:10.1023/A:1018513530268

Tregouboff, G., and Rose, M. (1978a). 'Manuel de Planctologie Méditerranéenne Tome I.' (CNRS: Paris, France.)

Tregouboff, G., and Rose, M. (1978b). 'Manuel de Planctonologie Méditerranéenne. Tome II.' (CNRS: Paris, France.)

US Environmental Protection Agency (1999). National recommended water quality criteria for priority pollutants - correction: EPA 822-Z-99-001. Report Number 4304T, US EPA Office of Water, Washington, DC, USA.

Wilhm, J. L. (1975). Biological indicators of pollution. In 'River Ecology'. (Ed. B. A. Whitton.) pp. 375-402. (Blackwell: Oxford, UK.)

Williams, J. A., and Muxagata, E. (2006). The seasonal abundance and production of Oithona nana (Copepoda: Cyclopoida) in Southampton Water. Journal of Plankton Research 28, 1055-1065. doi:10.1093/ PLANKT/FBL039

Wiwatanaratanabutr, I., and Grandjean, F. (2016). Impacts of temperature and crowding on sex ratio, fecundity and Wolbachia infection intensity in the copepod, Mesocyclops thermocyclopoides. Journal of Invertebrate Pathology 141, 18-23. doi:10.1016/J.JIP.2016.10.003

Zaghden, H., Kallel, M., Louati, A., Elleuch, B., Jean, O., and Saliot, A. (2005). Hydrocarbons in surface sediments from the Sfax coastal zone (Tunisia) Mediterranean Sea. Marine Pollution Bulletin 50, 1287-1294. doi:10.1016/J.MARPOLBUL.2005.04.045

Zakaria, H. Y., Abdel-Kader, M. H., Abo-Senna, F. M., and El-Naggar, H. A. (2016). Abundance, distribution, diversity and zoogeography of epipelagic copepods off the Egyptian coast (Mediterranean Sea). Egyptian Journal of Aquatic Research 42, 459-473. doi:10.1016/J.EJAR.2016. 11.001 